\title{
Toxoplasma gondii and Neospora caninum in dogs from the state of Tocantins: serology and associated factors
}

Toxoplasma gondii e Neospora caninum em cães provenientes de Tocantins: sorologia e fatores associados

Juliana Macedo Raimundoํㅜ Andresa Guimarães ${ }^{1}$; Larissa Martins de Brito Moraes'; Lucélia Azevedo Santos²; Leandro Lopes Nepomuceno²; Silvia Minharro Barbosa²; Marcus Sandes Pires ${ }^{1}$; Huarrisson Azevedo Santos ${ }^{1}$;

Carlos Luiz Massard ${ }^{1}$; Rosangela Zacarias Machado³; Cristiane Divan Baldani ${ }^{1 *}$

${ }^{1}$ Instituto de Veterinária, Universidade Federal Rural do Rio de Janeiro - UFRRJ, Seropédica, RJ, Brasil

${ }^{2}$ Universidade Federal de Tocantins - UFT, Araguaína, TO, Brasil

${ }^{3}$ Departamento de Patologia Veterinária, Universidade Estadual Paulista - UNESP, Jaboticabal, SP, Brasil

Received February 20, 2015

Accepted April 6, 2015

\begin{abstract}
This study investigated occurrences of anti-Neospora caninum and anti-Toxoplasma gondii IgG antibodies by means of the enzyme-linked immunosorbent assay (ELISA) and indirect immunofluorescence assay (IFAT), along with risk factors associated with toxoplasmosis and neosporosis, in $204 \mathrm{dogs}$ from urban and rural areas of the municipality of Araguaína, state of Tocantins, Brazil. One hundred and thirty samples (63.7\%) were positive for T. gondii using ELISA: $57.1 \%$ and $70.7 \%$ in the urban and rural areas, respectively. The seropositivity frequency for T. gondii observed through IFAT was $57.4 \%$, distributed between rural and urban areas as $62.6 \%$ and $52.4 \%$, respectively. The factors associated with canine toxoplasmosis were age and breed $(\mathrm{p}<0.05)$. In relation to $N$. caninum, 88 samples $(43.1 \%)$ were positive, according to ELISA, distributed as $42.9 \%$ in urban areas and $43.3 \%$ in rural areas. Anti - N. caninum antibodies were detected through IFAT in 62 dogs (30.4\%), distributed as $31.3 \%$ and $29.5 \%$ between rural and urban areas, respectively. Age and breed were associated with neosporosis occurrence $(\mathrm{p}<0.05)$ by IFAT. This study provides the first detection of IgG antibodies for canine toxoplasmosis and neosporosis in the state of Tocantins and highlights the importance of dogs in the epidemiological chain of these diseases.
\end{abstract}

Keywords: Dogs, toxoplasmosis, neosporosis, ELISA, IFAT.

\section{Resumo}

Este estudo investigou a ocorrência de anticorpos anti-Neospora caninum e anti-Toxoplasma gondii por ensaio imunoenzimático indireto (ELISA) e reaçáo de imunofluorescência indireta (RIFI), assim como os fatores de risco associados à toxoplasmose e à neosporose em 204 cães provenientes de áreas urbana e rural do município de Araguaína, Estado de Tocantins, Brasil. Cento e trinta amostras (63,7\%) foram positivas para T. gondii, destas $57,1 \%$ e 70,7\% oriundas de áreas urbanas e rurais, respectivamente. Considerando-se o teste RIFI, a frequência de soropositividade para T. gondii foi de 57,4\% com distribuição de $62,6 \%$ e 52,4\% entre áreas rurais e urbanas, respectivamente. Fatores associados à toxoplasmose canina foram raça e idade, com soropositividade maior para animais mais velhos $(\mathrm{p}<0,05)$. Em relação à $N$. caninum, $88(43,1 \%)$ amostras foram positivas, segundo ELISA, sendo distribuídas em $42,9 \%$ para área urbana e $43,3 \%$ para área rural. Por meio da RIFI, anticorpos anti- $N$. caninum foram detectados em $62(30,4 \%)$ cáes, sendo distribuídos em $31,3 \%$ e 29,5\% entre áreas rurais e urbanas, respectivamente. Os fatores associados à ocorrência de neosporose, pela RIFI, foram idade e raça $(\mathrm{p}<0,05)$. Este estudo representa a primeira detecção de anticorpos IgG para toxoplasmose e neosporose canina no Estado de Tocantins e evidencia a importância de cães na cadeia epidemiológica dessas doenças.

Palavras-chave: Cáes, toxoplasmose, neosporose, ELISA, RIFI.

*Corresponding author: Cristiane Divan Baldani. Laboratório de Patologia 


\section{Introduction}

Neospora caninum and Toxoplasma gondii are obligate intracellular protozoa that belong to the phylum Apicomplexa and family Sarcocystidae (DUBEY et al., 2002). They are etiological agents for neosporosis and toxoplasmosis, respectively. Both of these diseases have worldwide importance due to their cosmopolitan distribution and diversity of hosts, and also because they induce abortion in intermediate hosts and neurological, gastrointestinal and respiratory symptoms in dogs (MINEO et al., 2001; VALADAS et al., 2010). Since these diseases have similar structures and taxonomy, studies have been directed towards checking for possible coinfection.

Toxoplasmosis is a zoonosis with an etiological agent that can infect a wide range of domestic and wild animals, as well as humans. It has greater importance for women presenting primary infection during pregnancy, due to the risk of transmission to the fetus (SPALDING et al., 2002), and also for people with immunodeficiency (DUBEY et al., 2009).

Dogs are the definitive hosts of $N$. caninum (MCALLISTER et al., 1998) and are consequently responsible for excretion of oocysts in their feces, thereby spreading oocysts in the environment. One of the most important intermediate host, cattle once infected, may suffer abortion and reproductive failure, resulting in considerable consequent socioeconomic losses (THURMOND et al., 1997). Anti- $N$. caninum antibodies have already been detected in human samples, particularly in HIV-infected patients and patients with neurological disorders. Such patients might present opportunistic concurrent infections due to T. gondii (LOBATO et al., 2006). However, the zoonotic potential of $N$. caninum has not been totally established (BRESCIANI et al., 2007).

Infection of the dog by T. gondii means that the area involved provides an ecological niche for this protozoon, from the public health viewpoint. Consequently, this provides a risk for the human population (GERMANO et al., 1985), since dogs can serve as a source of infection for humans through mechanically spreading the protozoon and also through sharing sources of infection (DUBEY et al., 2009).

Because of the economic growth of the Amazon region and the current importance of this region in relation to development of the Brazilian meat industry, studies have been directed towards serological monitoring of $T$. gondii and $N$. caninum in canine populations. However, in northern Brazil, there are still only a few studies relating to occurrences of these agents, focusing on factors associated with parasitic infections. Among these, Valadas et al. (2010) found occurrence rates of $69.8 \%$ for $T$. gondii and $12.4 \%$ for $N$. caninum in the state of Pará. Cañón-Franco et al. (2003, 2004 ) in urban area of a city in the Rondônia State found that $8.3 \%$ of the dogs were seroreactive to $N$. caninum antigens and $76.4 \%$ to $T$. gondii. Furthermore, Aguiar et al. (2006) reported that the seroprevalence of $N$. caninum in dogs from rural area of Rondônia State were $12.6 \%$. Thus, the lack of epidemiological data relating to $N$. caninum and T. gondii in the state of Tocantins, where so far there have not been any reports of these agents, motivated the present study. The objective of this study was to determine occurrences of anti-N. caninum and anti-T. gondii IgG antibodies in serum samples from dogs in rural and urban areas of the municipality of Araguaína, Tocantins, so as to identify possible risk factors associated with seropositivity.

\section{Materials and Methods}

This study was conducted in the municipality of Araguaína ( $07^{\circ} 11^{\prime} 28^{\prime}$ S S, $\left.48^{\circ} 12^{\prime} 26^{\prime \prime} \mathrm{W}\right)$, state of Tocantins, central northern region of Brazil. Araguaína occupies an area of $4000.4 \mathrm{~km}^{2}$ and has a semi-humid tropical climate. According to demographic census 2010 from Brazilian Institute of Geography and Statistics, estimated total population of Araguaína municipality in 2010 was 150.484 , with 7.560 people distributed into rural areas and 142.924 in urban areas. A total of 204 dogs belonging to rural and urban areas were selected as a non-probability convenience sample, regardless of gender, breed or age. Ninety-nine dogs were sampled from ten villages and farms and 105 dogs from nine urban areas between April 2009 and February 2010.

A semi-structured questionnaire was applied to the owners of the dogs with the aim of identifying possible factors associated with occurrences of toxoplasmosis and neosporosis among dogs in the region studied, including gender, age, breed, presence of other pets in the dog's household, activity area, presence of cats and dogs in the household and consumption of hunted meat.

Blood samples were collected into sterile tubes without anticoagulant and were kept at $4{ }^{\circ} \mathrm{C}$ until arrival at the laboratory. Serum was then separated through centrifugation and was stored at $-20{ }^{\circ} \mathrm{C}$ until serological analysis.

The enzyme-linked immunosorbent assay (ELISA) for detection of $\mathrm{IgG}$ antibodies to $T$. gondii was performed as described by Domingues et al. (1998). Antigen was produced from purified tachyzoites ( $\mathrm{RH}$ strain) that were obtained through peritoneal washing in mice that had previously been infected. Briefly, microplates (Nunclon ${ }^{\mathrm{TM}}$ surface) were coated with antigen $(5 \mu \mathrm{g} / \mathrm{mL})$ diluted in carbonate-bicarbonate buffer (pH 9.6). Blocking was performed using PBS-Tween 20 (PBST) containing $6 \%$ milk powder. Incubation was performed with test and control serum samples diluted 1:200 in PBST containing $5 \%$ normal rabbit serum. Anti-canine IgG conjugate coupled with alkaline phosphatase (Sigma-Aldrich) diluted to 1:10.000 in PBS-Tween 20 plus 5\% normal rabbit serum was added as a secondary antibody. The reaction was developed through addition of the enzyme substrate, p-nitrophenyl phosphate $(1 \mathrm{mg} / \mathrm{mL})$. The reaction was read using a microplate reader (Labsystems IEMS Reader MF) at $405 \mathrm{~nm}$.

For $N$. caninum, the investigation of $\operatorname{IgG}$ antibodies was performed in accordance with Silva et al. (2007). In this, tachyzoites of Nc-1 strain of $N$. caninum that were maintained in VERO cells and purified by means of forcible extrusion were used as the antigen. The microplates were sensitized with antigen at $10 \mu \mathrm{g} / \mathrm{mL}$, blocked with PBS Tween 20 plus 6\% milk powder and incubated with test and control serum diluted 1:50 in PBST containing 5\% normal rabbit serum. After this point, the reaction was performed exactly as described above for $T$. gondii.

The immunological activity of each serum tested was calculated by determining the value of $\mathrm{S} / \mathrm{P}$, using the following equation: (absorbance of the sample - mean absorbance of the negative control serum) / (mean absorbance of positive serum controls mean negative control serum), taking negative and positive serum samples as the reference point. Positive reactions were those in 
which the absorbance was higher than the cutoff point obtained from each ELISA plate, as described by Machado et al. (1997).

The indirect immunofluorescence assay (IFAT) was performed as previously described by Camargo (1964) and Mineo (2007) in order to detect anti-T. gondii and anti-N. caninum IgG antibodies, respectively. Tachyzoites of the $T$. gondii $\mathrm{RH}$ strain obtained by means of intraperitoneal serial passages in Swiss mice and tachyzoites of $N$. caninum ( $\mathrm{Nc}-1$ strain) maintained by means of continuous passages in cultures of VERO cells were used as antigens. Cutoff dilutions of 1:40 and 1:25 were used for $T$. gondii and $N$. caninum, respectively. In each IFAT reaction, previously established positive and negative serum samples were included as controls and a FITC-conjugated monoclonal anti-dog IgG secondary antibody (Sigma-Aldrich ${ }^{\circledast}$ ) was used.

Positive and negative control serum for T. gondii and N. caninum were included in all the serological tests, donated by Dr. Rosangela Zacarias Machado, of the Immunoparasitology Laboratory, Department of Veterinary Pathology, UNESP, Jaboticabal.

The serological results were correlated, using the chi-square $\left(\mathrm{X}^{2}\right)$ or Fisher test at the $5 \%$ significance level, using BioEstat 5.0 software, with variables relating to gender, age, racial pattern, presence of other domestic animals, activity area, presence of cats and dogs in the household and consumption of hunted meat. The agreement between ELISA and IFAT was assessed using kappa (k) coefficients, as previously reported (ROSNER, 2006).

\section{Results}

Out of the total of 204 dogs sampled, the frequencies of seropositivity for $T$. gondii and $N$. caninum were $63.7 \%$ (130/204) and $43.1 \%$ (88/204), respectively, by means of the ELISA test. As described in Table 1, anti-T. gondii antibodies were detected in $70.7 \%$ (70/99) of the dogs in rural areas, whereas $43.4 \%(43 / 99)$ presented antibodies to $N$. caninum. A co-positivity percentage of $38.4 \%$ (38/99) was observed among the dogs in the rural area. Regarding domestic dogs in urban areas, the frequencies of antibodies were 57.1\% (60/105) and 42.9\% (45/105) against T. gondii and $N$. caninum, respectively. The co-positivity percentage for $T$. gondii and $N$. caninum was $32.4 \%$ (34/105). Considering IFAT, the frequencies of seropositivity were $57.4 \%(117 / 204)$ and $30.4 \%(62 / 204)$ for $T$. gondii and $N$. caninum, respectively. The distribution between rural and urban areas was $62.6 \%$ (62/99) and 52.4\% (55/105) for T. gondii and 31.3\% (31/99) and $29.5 \%(31 / 105)$ for $N$. caninum, respectively. Coinfection rates of $25.3 \%$ and $22.9 \%$ were observed for dogs in the rural and urban area, respectively.
Although there was no statistical association, a tendency towards infection by $T$. gondii among dogs in rural areas was observed (Table 1), with higher risk of toxoplasmosis in rural areas when compared with urban areas ( $p>0.05)$. In all rural and urban properties, at least one dog was positive for the agents studied.

The factors statistically associated with infection by $T$. gondii were breed and age $(\mathrm{p}<0.05)$. Dogs older than six months had higher prevalence than younger dogs $(<6 \mathrm{~m})$, as did mixed-breed dogs. On the other hand, only age was associated with infection with $N$. caninum $(\mathrm{p}<0.05)$, such that dogs older than six months showed higher seropositivity levels. However, the variables of gender, presence of other domestic animals, activity area, presence of cats in the household and consumption of raw meat were not statistically associated with seropositivity for $T$. gondii and $N$. caninum. Additionally, the variable of breed was not associated with $N$. caninum in analysis on the ELISA test results ( $p>0.05)$. However, mixed-breed dogs had more chance of becoming infected by the parasite, which was confirmed by the IFAT results $(\mathrm{p}<0.05)$ (Table 2$)$.

Analysis on correlations of the results from the 204 serum samples subjected to ELISA and IFAT in the presence of T. gondii antigens showed that 68 serum samples $(33.3 \%)$ were co-negative and 111 (54.4\%) were co-positive in both assays. Regarding detection of $N$. caninum antibodies, the co-negative and co-positive rates were $53(25.9 \%)$ and 107 (52.4\%), respectively. Comparing the two serological tests, good concordance was observed for $T$. gondii $(\kappa=0.74)$ and $N$. caninum $(\kappa=0.54)$, as defined by Rosner (2006). Comparative statistical analysis using the McNemar test showed that there was a significant effect at the $5 \%$ probability level $(\mathrm{p}<0.05)$ (Table 3).

\section{Discussion}

This study was the first report on the frequencies of $\mathrm{IgG}$ antibodies against Toxoplasma gondii and Neospora caninum in dogs in the state of Tocantins, in northern Brazil. The high frequency of anti-T. gondii antibodies in dogs $(63.7 \%$ according to ELISA and $57.4 \%$ from IFAT) observed in this study corroborates other Brazilian findings: Minervino et al. (2012) in Mato Grosso (52\%), Valadas et al. (2010) in Pará (69.8\%) and Cañón-Franco et al. (2004) in Rondônia (76.4\%). However, lower values for anti- $T$. gondii antibodies were observed in other Brazilian states, by Dantas et al. (2013) in Rio Grande do Norte (11.5\%) and Lopes et al. (2011) in Piauí (18\%). The data corresponding to the frequency of $T$. gondii in Brazil are discordant, which may be related to different serological tests, sample sizes, types of dog population

Table 1. Seropositivity for Toxoplasma gondii and Neospora caninum, by means of IFAT and ELISA, according to distribution of dogs from rural and urban areas of Araguaína, Tocantins, Brazil.

\begin{tabular}{|c|c|c|c|c|c|c|c|}
\hline \multicolumn{8}{|c|}{ Seropositivity } \\
\hline \multirow{2}{*}{ Area } & \multirow{2}{*}{$\begin{array}{c}\text { Number of } \\
\text { dogs }\end{array}$} & \multicolumn{2}{|c|}{ T.gondii (N/\%) } & \multicolumn{2}{|c|}{ N. caninum $(\mathrm{N} / \%)$} & \multicolumn{2}{|c|}{ Co-infection } \\
\hline & & ELISA & IFAT & ELISA & IFAT & ELISA & IFAT \\
\hline Rural & 99 & $70(70.7)^{\mathrm{a}}$ & $62(62.6)^{a}$ & $43(43.4)^{\mathrm{a}}$ & $31(31.3)^{\mathrm{a}}$ & $38(38.4)$ & $25(25.3)$ \\
\hline Urban & 105 & $60(57.1)^{a}$ & $55(52.4)^{\mathrm{a}}$ & $45(42.9)^{a}$ & $31(29.5)^{a}$ & $34(32.4)$ & $24(22.9)$ \\
\hline
\end{tabular}

Same letters in the same column do not differ by Chi-square test at $5 \%$ significance. N: number of positive dogs; \%: percentage of positive dogs. 
Table 2. Factors associated with IgG antibodies frequency for T. gondii and N. caninum in pet dogs in the city of Araguaína, Tocantins, Brazil.

\begin{tabular}{|c|c|c|c|c|c|c|c|c|c|}
\hline \multirow{3}{*}{ Variable } & \multirow{3}{*}{$\operatorname{Dogs}(\mathrm{N})$} & \multicolumn{4}{|c|}{ Toxoplasma gondii } & \multicolumn{4}{|c|}{ Neospora caninum } \\
\hline & & \multicolumn{2}{|c|}{ ELISA } & \multicolumn{2}{|c|}{ IFAT } & \multicolumn{2}{|c|}{ ELISA } & \multicolumn{2}{|c|}{ IFAT } \\
\hline & & $\begin{array}{l}\text { Positive } \\
(\%)\end{array}$ & $\underset{\left(X^{2}\right)}{\mathbf{p}}$ & $\begin{array}{c}\text { Positive } \\
(\%)\end{array}$ & $\underset{\left(X^{2}\right)}{\mathbf{p}}$ & $\begin{array}{l}\text { Positive } \\
(\%)\end{array}$ & $\underset{\left(X^{2}\right)}{\mathbf{p}}$ & $\begin{array}{l}\text { Positive } \\
(\%)\end{array}$ & $\underset{\left(X^{2}\right)}{\mathbf{p}}$ \\
\hline \multicolumn{10}{|l|}{ Age } \\
\hline$<6 \mathrm{~m}$ & 37 & $14(37.8)^{\mathrm{b}}$ & & $15(40.5)^{\mathrm{a}}$ & & $10(27.0)^{\mathrm{b}}$ & & $7(18.9)^{a}$ & \\
\hline$>6 \mathrm{~m}-<2 \mathrm{y}$ & 96 & $62(64.6)^{a}$ & 0.0094 & $56(58.3)^{\mathrm{a}}$ & 0.0991 & $40(41.7)^{\mathrm{ba}}$ & 0.1731 & $27(28.1)^{a}$ & 0.3849 \\
\hline$>2-<5 y$ & 51 & $38(74.5)^{\mathrm{a}}$ & 0.0012 & $32(62.7)^{a}$ & 0.0651 & $25(49.0)^{\mathrm{ba}}$ & 0.0629 & $19(37.3)^{\mathrm{a}}$ & 0.1043 \\
\hline$>5 \mathrm{y}$ & 20 & $16(80.0)^{\mathrm{a}}$ & 0.0048 & $14(70.0)^{\mathrm{a}}$ & 0.0518 & $13(65.0)^{a}$ & 0.0100 & $9(45.0)^{\mathrm{a}}$ & 0.0622 \\
\hline \multicolumn{10}{|l|}{ Gender } \\
\hline Female & 86 & $53(61.6)^{a}$ & & $48(55.8)^{\mathrm{a}}$ & & $32(37.2)^{\mathrm{a}}$ & & $21(24.4)^{a}$ & \\
\hline Male & 118 & $77(65.3)^{\mathrm{a}}$ & 0.7006 & $69(58.5)^{a}$ & 0.8134 & $56(47.5)^{a}$ & 0.1881 & $41(34.7)^{\mathrm{a}}$ & 0.1529 \\
\hline \multicolumn{10}{|l|}{ Breed } \\
\hline Pure breed & 29 & $139(44.8)^{\mathrm{b}}$ & & $9(31.0)^{\mathrm{b}}$ & & $8(27.6)^{a}$ & & $3(10.3)^{b}$ & \\
\hline Mixed-breed & 175 & $117(66.9)^{\mathrm{a}}$ & 0.0378 & $108(61.7)^{\mathrm{a}}$ & 0.0039 & $80(45.7)^{\mathrm{a}}$ & 0.1045 & $59(33.7)^{a}$ & 0.0094 \\
\hline \multicolumn{10}{|l|}{ Activity area } \\
\hline Inside the house & 21 & $10(47.6)^{\mathrm{a}}$ & & $10(47.6)^{a}$ & & $9(42.9)^{a}$ & & $6(28.6)^{a}$ & \\
\hline Yard/Street & 183 & $120(65.5)^{\mathrm{a}}$ & 0.1489 & $107(58.5)^{a}$ & 0.3604 & $79(43.2)^{\mathrm{a}}$ & 1.0000 & $56(30.6)^{a}$ & 1.0000 \\
\hline \multicolumn{10}{|c|}{ Presence of other animals } \\
\hline No & 35 & $17(48.6)^{\mathrm{a}}$ & & $15(42.9)^{\mathrm{a}}$ & & $11(31.4)^{\mathrm{a}}$ & & $9(25.7)^{a}$ & \\
\hline Yes & 169 & $113(66.9)^{\mathrm{a}}$ & 0.0635 & $102(60.4)^{\mathrm{a}}$ & 0.1636 & $77(45.6)^{\mathrm{a}}$ & 0.1773 & $53(31.4)^{\mathrm{a}}$ & 0.6461 \\
\hline \multicolumn{10}{|l|}{ Presence of cats } \\
\hline No & 115 & $74(64.3)^{\mathrm{a}}$ & & $65(56.5)^{a}$ & & $21(38.9)^{a}$ & & $38(33)^{a}$ & \\
\hline Yes & 54 & $39(72.2)^{\mathrm{a}}$ & 0.4016 & $37(68.5)^{a}$ & 0.1875 & $56(48.7)^{a}$ & 0.3039 & $15(27.8)^{\mathrm{a}}$ & 0.6099 \\
\hline \multicolumn{10}{|l|}{ Presence of dogs } \\
\hline No & 124 & - & & - & & $56(45.2)^{\mathrm{a}}$ & & $16(35.6)^{a}$ & \\
\hline Yes & 45 & - & & - & & $21(46.7)^{\mathrm{a}}$ & 0.9992 & $37(29.8)^{a}$ & 0.3171 \\
\hline \multicolumn{10}{|c|}{$\begin{array}{l}\text { Consumption of hunted } \\
\text { meat }\end{array}$} \\
\hline No & 174 & $108(62.1)^{\mathrm{a}}$ & & $96(55.2)^{\mathrm{a}}$ & & $75(43.1)^{\mathrm{a}}$ & & $51(29.3)^{\mathrm{a}}$ & \\
\hline Yes & 30 & $22(73.3)^{\mathrm{a}}$ & 0.3273 & $21(70)^{\mathrm{a}}$ & 0.1626 & $13(43.3)^{\mathrm{a}}$ & 0.8602 & $11(36.7)^{\mathrm{a}}$ & 0.5192 \\
\hline
\end{tabular}

Same letters in the same column do not differ by Chi-square test at 5\% significance. N: number of total dogs; m: months; y: years.

Table 3. Number and percentages (n/\%) of dogs serum tested by IFAT and ELISA, co-positive or co-negative in the presence of T. gondii and $N$. caninum antigens, in the city of Araguaína, Tocantins, Brazil.

\begin{tabular}{ccccc}
\hline \multirow{2}{*}{ IFAT } & \multicolumn{2}{c}{ Toxoplasma gondii } & \multicolumn{2}{c}{ Neospora caninum } \\
\cline { 2 - 5 } & \multicolumn{3}{c}{ ELISA test } & Negative \\
Positive & Positive & Negative & Positive & $9(4.4 \%)$ \\
Negative & $111(54.4 \%)$ & $19(9.4 \%)$ & $53(26 \%)$ & $107(52.5 \%)$ \\
\hline
\end{tabular}

and cutoff tests (AZEVEDO et al., 2005), as well as climate and regional characteristics (DUBEY \& SCHARES, 2011). ELISA is a highly sensitive serological assay, and this feature can generate false positive results. Thus, the IFAT test was also performed, with the aim of eliminating the possibility of false positive samples at the high frequencies observed in previous studies. However, even using IFAT, the seropositivity for $T$. gondii was still higher than in previous studies, and good concordance $(\kappa=0.74)$ was observed between the two tests.

Regarding the study area, seropositivity for $T$. gondii was more frequently observed among dogs from rural areas $(70.7 \%$ according to ELISA and $62.6 \%$ from IFAT), which corroborates reports by Garcia et al. (1999) and Valadas et al. (2010), who found $78.8 \%$ and $70.8 \%$, respectively. Even though there was no statistically association, dogs from rural areas had a higher risk of infection than those in urban areas, due to greater exposure to intermediate hosts that were possibly infected by the agent in question. The high level of infection of the dog population in this study indicates that the area involved had high circulating levels of the protozoon, which consequently confers a risk of infection for the human population (GERMANO et al., 1985).

Taking into account the dog's age as an associated factor for T. gondii infection, there was a positive association between animals aged more than six months and parasite infection, according to the ELISA test. The IFAT results show clearly that there was a higher risk of infection with increasing age, especially among 
dogs older than 2 years, even though there was no statistical association. These results emphasize that the likelihood of infection increases with the dogs' ages and is in agreement with previous studies (CÁNÓN-FRANCO et al., 2004; DANTAS et al., 2013; LANGONI et al., 2013). In the present study, there was a significant difference regarding dogs seropositive for $T$. gondii between those with and without a defined breed $(p<0.05)$, which was in agreement with Moura et al. (2009). These results are probably related to the type of management to which dogs without a defined breed are subjected. However, Dantas et al. (2013) and Langoni et al. (2013) did not observe any association between seropositivity and breed.

The lack of statistical association between activity area, consumption of hunted meat, presence of other pets and cats in the household and presence of antibodies against $T$. gondii was not expected, since dogs kept in this context would theoretically have greater exposure to sources of infection. However, the risk of infection by $T$. gondii was higher among dogs with access to the yard $(65.6 \%)$, those that consumed hunted meat $(73.3 \%)$ and those living with other domestic species (66.9\%), according to the ELISA test. Similar results concerning the presence of domestic cats and the type of activity area were reported by Bresciani et al. (2007). In contrast, Moura et al. (2009) demonstrated a positive correlation between these two variables and infection by T. gondii. Even though dogs from rural areas were more prone to be infected by $T$. gondii $(77.3 \%)$ than those living in urban areas $(50 \%)$, there was no statistical association with infection. The greater infection rate among dogs from rural areas (77.3\%) reflected their consumption of hunted meat, and this was shown in the IFAT results analysis (data not shown).

Occurrences of $N$. caninum among dogs in Brazil have been studied in different regions, with rates ranging from $3.1 \%$ to $67.6 \%$, according to the review by Dubey \& Schares (2011). In the present study, taking into consideration the ELISA (43.1\%) and IFAT $(30.4 \%)$ test results, a higher frequency of antibodies against $N$. caninum was observed than in other studies conducted in different regions of Brazil (DANTAS et al., 2013; LANGONI et al., 2013; LOPES et al., 2011; MELO et al., 2012; MINERVINO et al., 2012; SICUPIRA et al., 2012; VALADAS et al., 2010). Additionally, no difference in the infection levels between rural and urban areas was observed, thus corroborating the findings of Valadas et al. (2010). However, Cunha et al. (2008), Fernandes et al. (2004) and Sicupira et al. (2012) found that dogs belonging to rural areas had higher seropositivity than dogs in urban areas. Thus, due to the differences in the numbers of samples, diagnostic techniques and cutoff points, such comparisons should be made cautiously.

Among the risk factors evaluated, only age was associated with seropositivity for $N$. caninum, according to the ELISA test. The infection levels observed were directly proportional to increasing age, i.e. the risk of infection became higher with longer exposure to the protozoon, thus demonstrating that horizontal transmission of this agent was occurring. Similar data were reported in previous studies (AGUIAR et al., 2006; CUNHA et al., 2008; FERNANDES et al., 2004; MINERVINO et al., 2012). However, Azevedo et al. (2005), Bresciani et al. (2007), Dantas et al. (2013), Langoni et al. (2013) and Melo et al. (2012) did not find any correlation between age and the presence of anti- $N$. caninum antibodies. The IFAT results did not show any positive association with $N$. caninum infection, although they demonstrated that the dogs were more prone to becoming infected as they grew older.

The variables of gender and breed were not associated with seropositivity for $N$. caninum, according to the ELISA test analysis. On the other hand, mixed-breed dogs showed a statistically higher risk of infection than that of purebred dogs, according to the IFAT analysis ( $\mathrm{p}<0.05)$. Lopes et al. (2011), Azevedo et al. (2005), Sicupira et al. (2012) and Langoni et al. (2013) did not find any association between $N$. caninum infection and gender or breed, thus suggesting that there is no predisposition according to breed or gender susceptibility in relation to occurrences of canine neosporosis. On the other hand, Melo et al. (2012) observed high frequency of seropositivity to $N$. caninum in purebred dogs, although no statistical association was found.

In this study, the presence of other domestic animals, activity area, presence of cats and dogs in the household and consumption of hunted meat were not statistically associated with occurrences of antibodies against $N$. caninum. On the other hand, several other studies have reported that these factors were risk factors because they led to greater exposure to the protozoon (SICUPIRA et al., 2012; DANTAS et al., 2013). Notably, and in agreement with our findings, there were no positive associations between occurrences of neosporosis and the presence of dogs and cattle or the presence of cats and rodents in previous studies (AZEVEDO et al., 2005; CUNHA et al., 2008). However, dogs that lived in the presence of other animals generally showed three times more chance of becoming infected by $N$. caninum $(\mathrm{p}<0.05)$. Concordant with our results, Bresciani et al. (2007) and Sicupira et al. (2012) also did not observe any association between dog activity area and neosporosis. Likewise, other authors have reported a strong association between occurrences of the agent and access by dogs to the streets (AZEVEDO et al., 2005; BENETTI et al., 2008). Moreover, Benetti et al. (2008) reported that because of hunting practices, dogs with access to the streets had a higher risk of infection than those that were strictly confined to the home.

Although differences in seropositivity rates for $T$. gondii and $N$. caninum were observed between the results from ELISA and IFAT, the results from the kappa test demonstrated good concordance. Differences in the sensitivity and specificity of the serological tests used and in the cutoffs established for each test have been reported (BJORKMAN \& UGGLA, 1999). Therefore, suitable comparisons between prevalence rates are not always possible. In addition, it is widely known that the soluble antigen extracts used in ELISA contain a large number of antigens, particularly those of intracellular origin, whereas parasite surface membrane antigens are preferentially recognized in IFAT (SILVA et al., 2007). Furthermore, in the present study, higher prevalence rates for T. gondii and N. caninum were observed using ELISA than using IFAT. Thus, IFAT has been considered to be a more species-specific test, although its sensitivity and specificity can be altered based on the cutoff values established (BJORKMAN \& UGGLA, 1999).

In conclusion, the high seropositivity for T. gondii (63.7\%) and $N$. caninum $(43.1 \%)$ in the canine population of the municipality of Araguaína suggested that infection by these agents had high frequency in this region. We have provided the first serological detection of T. gondii and $N$. caninum in the state of Tocantins, 
Brazil. Additionally, this study emphasizes that public-health monitoring activities relating to occurrences of toxoplasmosis need to include investigation of dogs' roles in this, because of the common sources of infection between dogs and humans.

\section{References}

Aguiar DM, Cavalcante GT, Rodrigues AAR, Labruna MB, Camargo LMA, Camargo EP, et al. Prevalence of anti-Neospora caninum antibodies in cattle and dogs from Western Amazon, Brazil, in association with some possible risk factors. Vet Parasitol 2006; 142(1-2): 71-77. http://dx.doi. org/10.1016/j.vetpar.2006.06.014. PMid:16857319.

Azevedo SS, Batista CSA, Vasconcellos SA, Aguiar DM, Ragozo AMA, Rodrigues AAR, et al. Seroepidemiology of Toxoplasma gondii and Neospora caninum in dogs from the state of Paraíba, Northeast region of Brazil. Res Vet Sci 2005; 79(1): 51-56. http://dx.doi.org/10.1016/j. rvsc.2004.10.001. PMid:15894024.

Benetti AH, Toniollo GH, Santos TR, Gennari SM, Costa AJ, Dias RA. Ocorrência de anticorpos anti-Neospora caninum em cães no município de Cuiabá, Mato Grosso. Cienc Anim Bras 2008; 9(1): 177-180.

Björkman C, Uggla A. Serological diagnosis of Neospora caninum infection. Int J Parasitol 1999; 29(10): 1497-1507. http://dx.doi.org/10.1016/ S0020-7519(99)00115-0. PMid:10608435.

Bresciani KDS, Costa AJ, Nunes CM, Serrano ACM, Moura AB, Stobbe NS, et al. Ocorrência de anticorpos contra Neospora caninum e Toxoplasma gondii e estudo de fatores de risco em cães de Araçatuba-SP. ARS Vet 2007; 23(1): 40-46.

Camargo ME. Improved technique of indirect immunofluorescence for serological diagnosis of toxoplasmosis. Rev Inst Med Trop Sao Paulo 1964; 6(3): 117-118. PMid:14177810.

Cañón-Franco WA, Bergamaschi DP, Labruna MB, Camargo LMA, Souza SLP, Silva JCR, et al. Prevalence of antibodies to Neospora caninum in dogs from Amazon, Brazil. Vet Parasitol 2003; 115(1): 71-74. http:// dx.doi.org/10.1016/S0304-4017(03)00131-6. PMid:12860070.

Cañón-Franco WA, Bergamaschi DP, Labruna MB, Camargo LMA, Silva JCR, Pinter A, et al. Occurrence of anti- Toxoplasma gondii antibodies in dogs in the urban area of Monte Negro, Rondônia, Brazil. Vet Res Commun 2004; 28(2): 113-118. http://dx.doi.org/10.1023/ B:VERC.0000012114.71235.73. PMid:14992241.

Cunha NA Fo, Lucas AS, Pappen FG, Ragozo AMA, Gennari SM, Lucia $\mathrm{T}$ Jr, et al. Fatores de risco e prevalência de anticorpos anti-Neospora caninum em cáes urbanos e rurais do Rio Grande do Sul, Brasil. Rev Bras Parasitol Vet 2008;17(Suppl 1): 301-306. PMid:20059865.

Dantas SBA, Fernandes ARF, Souza OLS No, Mota RA, Alves CJ, Azevedo SS. Ocorrência e fatores de risco associados às infecçóes por Toxoplasma gondii e Neospora caninum em cães do município de Natal, Estado do Rio Grande do Norte, Nordeste do Brasil. Cienc Rural 2013; 43(11): 2042-2048. http://dx.doi.org/10.1590/S0103-84782013001100020.

Domingues LM, Machado RZ, Costa MT, Carvalho CS, Costa AJ, Malheiros EB. Canine toxoplasmosis: a comparative evaluation of the detection of anti-Toxoplasma gondii antibodies by the indirect immunoenzymatic assay (ELISA) and the indirect immunofluorescence reaction (IIF). Rev Bras Parasitol Vet 1998; 7(2): 79-85.

Dubey JP, Barr BC, Barta JR, Bjerkas I, Björkman C, Blagburn BL, et al. Redescription of Neospora caninum and its differentiation from related coccidia. Int J Parasitol2002; 32(8): 929-946. http://dx.doi.org/10.1016/ S0020-7519(02)00094-2. PMid:12076623.

Dubey JP, Lindsay DS, Lappin MR. Toxoplasmosis and other intestinal coccidial infections in cats and dogs. Vet Clin North Am Small Anim Pract 2009; 39(6): 1009-1034, v. http://dx.doi.org/10.1016/j.cvsm.2009.08.001. PMid:19932360.

Dubey JP, Schares G. Neosporosis in animals: the last five years. Vet Parasitol 2011; 180(1-2): 90-108. http://dx.doi.org/10.1016/j.vetpar.2011.05.031. PMid:21704458.

Fernandes BCTM, Gennari SM, Souza SLP, Carvalho JM, Oliveira WG, Cury MC. Prevalence of anti-Neospora caninum antibodies in dogs from urban, periurban and rural areas of the city of Uberlândia, Minas Gerais - Brazil. Vet Parasitol 2004; 123(1-2): 33-40. http://dx.doi.org/10.1016/j. vetpar.2004.05.016. PMid:15265569.

Garcia JC, Navarro IT, Ogawa L, Oliveira RC, Kobilka E. Soroprevalência, epidemiologia e avaliação ocular da toxoplasmose humana na zona rural de Jaguapitã (Paraná), Brasil. Rev Panam Salud Publica 1999; 6(3): 157-163. http://dx.doi.org/10.1590/S1020-49891999000800002. PMid:10517092.

Germano PML, Erbolato EB, Ishizuka MM. Estudo sorológico da toxoplasmose canina, pela prova de imunofluorescência indireta, na cidade de Campinas, 1981. Rev Fac Med Vet Zootec Univ São Paulo 1985; 22(1): 53-58. http://dx.doi.org/10.11606/issn.2318-3659.v22i1p53-58.

Langoni H, Fornazari F, Silva RC, Monti ET, Villa FB. Prevalence of antibodies against Toxoplasma gondii and Neospora caninum in dogs. Braz J Microbiol 2013; 44(4): 1327-1330. http://dx.doi.org/10.1590/ S1517-83822013000400043. PMid:24688530.

Lobato J, Silva DAO, Mineo TWP, Amaral JDHF, Segundo GRS, Costa-Cruz JM, et al. Detection of immunoglobulin G antibodies to Neospora caninum in humans: high seropositivity rates in patients who are infected by human immunodeficiency virus or have neurological disorders. Clin Vaccine Immunol 2006; 13(1): 84-89. http://dx.doi. org/10.1128/CVI.13.1.84-89.2006. PMid:16426004.

Lopes MG, Mendonça IL, Fortes KP, Amaku M, Pena HFJ, Gennari SM. Presence of antibodies against Toxoplasma gondii, Neospora caninum and Leishmania infantum in dogs from Piauí. Rev Bras Parasitol Vet 2011; 20(2): 111-114. http://dx.doi.org/10.1590/S1984-29612011000200004. PMid:21722484.

Machado RZ, Montassier HJ, Pinto AA, Lemos EG, Machado MRF, Valadão IFF, et al. An enzyme-linked immunosorbent assay (ELISA) for the detection of antibodies against Babesia bovis in cattle. Vet Parasitol 1997; 71(1): 17-26. http://dx.doi.org/10.1016/S0304-4017(97)000034. PMid:9231985.

McAllister MM, Dubey JP, Lindsay DS, Jolley WR, Willis RA, McGuire AM. Dogs are definitive hosts of Neospora caninum. Int J Parasitol 1998; 28(9): 1473-1478. http://dx.doi.org/10.1016/S0020-7519(98)00138-6. PMid:9770635.

Melo ALT, Silva GCP, Aguiar DM. Soroprevalência de anticorpos antiNeospora caninum em cães da cidade de Cuiabá, Estado de Mato Grosso. Semina: Ciênc Agrár 2012; 33(4): 1507-1514.

Mineo TWP, Silva DAO, Costa GHN, Von Ancken ACB, Kasper LH, Souza MA, et al. Detection of IgG antibodies to Neospora caninum and Toxoplasma gondii in dogs examined in a veterinary hospital from Brazil. Vet Parasitol 2001; 98(4): 239-245. http://dx.doi.org/10.1016/S03044017(01)00441-1. PMid:11423182. 
Mineo TWP. Estudo da resposta imune celular e humoral de cães frente à infecção oral por Neospora caninum [Thesis]. Jaboticabal: Universidade Estadual Paulista; 2007.

Minervino AHH, Cassinelli ABM, Lima JTR, Soares HS, Malheiros AF, Marcili A, et al. Prevalence of Anti-Neospora caninum and Anti-Toxoplasma gondii antibodies in dogs from two different indigenous communities in the Brazilian Amazon region. J Parasitol 2012; 98(6): 1276-1278. http:// dx.doi.org/10.1645/GE-3151.1. PMid:22551468.

Moura AB, Souza AP, Sartor AA, Bellato V, Teixeira EB, Pisetta GM, et al. Ocorrência de anticorpos e fatores de risco para infecção por Toxoplasma gondii em cães, nas cidades de Lages e Balneário Camboriú, Santa Catarina, Brasil. Rev Bras Parasitol Vet 2009; 18(3): 52-56. http://dx.doi. org/10.4322/rbpv.01803009. PMid:19772776.

Rosner B. Fundamentals of Biostatistics. Boston: Duxbury Press; 2006.

Sicupira PML, Magalhães VCS, Galvão GS, Pereira MJS, Gondim LFP, Munhoz AD. Factors associated with infection by Neospora caninum in dogs in Brazil. Vet Parasitol 2012; 185(2-4): 305-308. http://dx.doi. org/10.1016/j.vetpar.2011.09.029. PMid:22015062.
Silva DA, Lobato J, Mineo TWP, Mineo JR. Evaluation of serological tests for the diagnosis of Neospora caninum infection in dogs: Optimization of cut off titers and inhibition studies of cross-reactivity with Toxoplasma gondii. Vet Parasitol 2007; 143(3-4): 234-244. http://dx.doi.org/10.1016/j. vetpar.2006.08.028. PMid:16973287.

Spalding SM, Amendoeira MRR, Coelho JMC, Angel SO. Otimização da relação de polimerase em cadeia para detecção de Toxoplasma gondii em sangue venoso e placenta de gestantes. J Bras Patol Med Lab 2002; 38(2): 105-110. http://dx.doi.org/10.1590/S1676-24442002000200006.

Thurmond MC, Hietala SK, Blanchard PC. Herd-based diagnosis of Neospora caninum-induced endemic and epidemic abortion in cows and evidence for congenital and postnatal transmission. J Vet Diagn Invest 1997; 9(1): 44-49. http://dx.doi.org/10.1177/104063879700900108. PMid:9087924.

Valadas S, Minervino AHH, Lima VMF, Soares RM, Ortolani EL, Gennari SM. Occurrence of antibodies anti-Neospora caninum, antiToxoplasma gondii, and anti-Leishmania chagasi in serum of dogs from Pará State, Amazon, Brazil. Parasitol Res 2010; 107(2): 453-457. http:// dx.doi.org/10.1007/s00436-010-1890-2. PMid:20445991. 